\title{
Developing Professional Competence of Faculty and Students of Civil ENGINEERING TO MEET THE GLOBAL STANDARDS
}

\author{
Dr. Suresh E.S.M $M^{1}$ and Beena B $R^{2}$ \\ ${ }^{1}$ National Institute of Technical Teachers Training and Research, Chennai, India \\ ${ }^{2}$ Federal Institute of Science and Technology, Kerala, India \\ esmsuresh@gmail.com, beenabr@gmail.com.
}

\begin{abstract}
In 21st century, the major challenge in engineering education in India is to meet the demands of technical profession and emerging job market. Now a days the education pattern, nature of jobs and services are fast changing across the world. Skill is becoming a commodity that can be bought from low-cost providers anywhere across the globe. Also in the digital world, knowledge is no longer confined to experts only, rather computer and internet connectivity has empowered every citizen to look for anything and everything. In this context, the engineering education of any country is very critical/crucial for determining its global positioning as well as ensuring the prosperity of their citizens. So engineering education system should be modified to enable our students to develop the skills like creativity and innovation, communication, critical thinking, interpersonal skills, collaboration and teamwork. Communication and collaboration are identified as an essential competencies by almost all of the organizations who are seeking competent employees. All the professional/accreditation bodies like Accreditation Board for Engineering and Technology (ABET), Washington Accord or National Board of Accreditation (NBA), India have already elaborately stated about the students learning outcomes, program educational outcomes, list of competencies, professional/ ethical responsibilities of engineers/ engineering educators/ academic institutions.

The aim of this study is to define parameters for measuring competence required for engineering faculty and students in meeting the global standards. The study also focused to discuss current scenario of Indian engineering education system giving special attention to Kerala. Also, the study aspired to develop a competence measuring model.
\end{abstract}

Keywords: Engineering Education, Professional Competence, Global Standards. India, Kerala, Competence measuring model.

\section{INTRODUCTION}

The role of engineers is to design and create successful systems, applying the scientific and mathematical knowledge, that lead to an improved quality of life, comply with realistic constraints such as technical, economic, business, political, social, and ethical issues. The role and responsibility of engineer varied with dynamic growth of the society. Hence engineering education should be carefully planned and executed to enable the students to develop necessary skills and competencies to continue life-long learning and thereby enabling them to face societal challenges beyond their technical proficiency. The success of the engineering program is measured by the high competence of its graduates in their professional career as well as the full satisfaction of their employers and society. So the engineering colleges have to review their programs continuously to graduate engineers with high scientific and professional attributes that enhance their contribution in the engineering market, especially with the growing demand on highly qualified engineers to deal with challenges facing today. In this paper parameters for measuring competence as well as a model for measuring competence were discussed .Also, the present scenario of engineering education in India, especially Kerala were discussed.

\section{LITERATURE REVIEWS}

As the number of engineers graduating increases day by day, the surplus quantity of professionals is available in the present job market across the world, thereby the demand for globally competent engineering graduates is very high. Competence means a cluster of abilities, commitments, knowledge, and skills that enable a person to act effectively in a job situation. In the following session the definition of competence and scale to measure it, was discussed. 
In paper [1] thirteen dimension or attributes of global competencies and its relative importance was proposed by conducting a survey on engineering educators and industry representatives as part of a National Science Foundation sponsored summit on global engineering education. From the study author concluded that by understanding more dimensions of global competence, universities can design learning activities to develop those competence for engineering graduates.

As a continuation to the above study author [2] conducted an online survey by expanding the sample size and collecting more demographic data about the participants. To compare the results author had taken weighted average between their data and Parkinson's [1] data set. From the study author concluded that the attainment of all the thirteen attributes of competences is challenging. But engineering universities should focus their education on the top three dimensions of global competence namely good communication skills, appreciation of cultural difference and teamwork. Proficiency in those areas should allow engineering graduates to not only be more globally competent employees, but also most culturally diverse individuals.

In the papers [3][4], rigorous tests to develop and validate a scale to measure contextual competence was discussed. Contextual competence is defined as engineer's ability to anticipate and understand the constraints and impacts of social, cultural, environmental, political and other contexts on engineering solutions. In these study responses from more than 5000 engineering students of 31 four-year institutions were involved. The study focused on the validity of scale (based on the content, structural, discriminant and concurrent values) by executing pilot test and factor analyses. The study also aimed to evaluate the scale's ability to measure how contextual competence varied based on several student demographic backgrounds, such as gender, citizenship, class year, and academic discipline. The paper presented the process required for developing and validating a scale to evaluate contextual competence. Similar procedure can also be used to develop a scale used to measures of any other learning outcomes and evaluate its validity for both local and large-scale assessments.

Lattuca et.al continued the above studies in the paper [5] and presented the influence of curricular and cocurricular characteristics as well as beliefs of faculty in their programs on students inter disciplinary skills. Also, how the precollege characteristics influenced the interdisciplinary competence of students. The data collected in the paper [4] was used for this study also. But the limitation of the study was all measures used were respondents self-reports. Hierarchical linear modeling was used in the analysis and the results of the student and program-level models that incorporated all independent variable blocks into a composite model were considered for the study. The results showed the extent of relationship between precollege characteristics, curricular and co-curricular experiences with interdisciplinary skills. The study also showed that there is no stronger correlation between faculty members beliefs and the students interdisciplinary skills.

In the study [6] exploratory factor analysis and confirmatory factor analysis were carried out to design and validate a measuring instrument to evaluate the performance of university professors. This was done based on the suggestions from the experts as well as from factor analysis. The Evaluation of Teaching Performance questionnaire was finalized with twenty eight items. The questionnaire were grouped into three dimensions: planning, development, and result. The internal consistency of instrument was analyzed using Cronbach's alpha coefficient and the descriptive statistics and bi-variate correlations of all items were obtained. Statistical packages tools like SPSS 21.0 and AMOS 21.0 were used for data analysis. From the three dimensions namely planning, development and result evaluated showed good internal consistency $(.70, .91$ and .79 , respectively), which guarantees the instrument's reliability. In this study data analysis was focused on students alone, even though this assessment was necessary but it was not sufficient. The analysis should include faculty self-evaluations, reports from persons outside the institution, work colleagues etc., thereby achieving a more comprehensive teaching evaluation, as this type of evaluation offers valuable information from different perspectives, for improving the evaluation quality. Also longitudinal studies may also be considered to analyze the validity of this scale's content and construct, expanding the sample of students, and estimating structural regression models to support the results obtained.

In the study [7] author proposed a conceptual model explaining the factors that influence global competency levels, and also identifies the baseline levels of global competency for benchmarking. The study also focused to evaluate how participation in study abroad programs, international experiences, culturally-relevant curricula, and other related activities can contribute to changes in students' ability to work in diverse environments. The survey was administered to first-year engineering students at a large, Midwestern research-intensive institution using fifteen items MGUDS-S survey. The examination focused on students backgrounds and their global competency levels in the first-year and later considered the trajectory 
of each students in terms of changes in global competency based on individual background and pre-college experiences, and as well as diversity-related collegeexperiences in which he or she engaged. Influence of students demographic factors and the influence of previous experiences were used as the elements of data collection. Ordinary least square regression models were used to examine the significant factors that are associated with changes in the MGUDS-S scores. Different factors for global competency used in the MGUDS-S scores are 1) Diversity of contact, (2) Relativistic appreciation, (3) Comfort with differences, and (4) Total MGUDS-S score. Considering separately for domestic and international students. All significant level considered was $\alpha=0.10$. Scatter plot matrix was used to compare the data. Women and underrepresented minority students, as well as international students have higher global competency scores as measured by the MGUDS-S compared to men. The finding supported the programs that promote student travel abroad experiences and increased interactions between diverse groups of students .Also, the study highlighted the influence of pre-collegiate factors in determining potential changes and increases in students global competency levels.

From these literatures various dimensions of global competence, scale to measure it, validity of the scale etc were explained, which can be used for similar types of studies. In the present study parameters for competence level of faculty and students as well a model to measure it was discussed.

\section{ENGINEERING EDUCATION - INDIAN SCENARIO}

The technical education in India was started in the year 1794 with the establishment of survey school at Chennai. Later in 1847 the first Engineering College in India was started at Roorkee. By 1947, there were 36 Engineering Colleges in India with an annual intake of 2500 students. In 1945 UGC established All India Council for Technical Education (AICTE) as an advisory board for technical education and later in 1987 it was enhanced as an autonomous statutory body to standardize the process and quality of Engineering and Technology education to all sections of the society across India. Later in 1994 The National Board of Accreditation (NBA), India was initially established by AICTE for periodic evaluations of technical institutions \& programs basis according to specified norms and standards as recommended by AICTE.

From 1992 onwards there is a tremendous growth in the number of Engineering College in India from 400 to 3500 today, when the University affiliation systems were opened to private investors. The mushrooming of engineering colleges, as well as the business attitude in running engineering colleges, resulted in low quality of engineering education in the country. Later in order to fill vacant seats in engineering colleges, admission is given to students who passed the $10+2$ system of secondary school education with physics, chemistry and mathematics back ground and a bare minimum mark of $45 \%$ in the qualifying School leaving examination. Accomplishing engineering degree for such low performing students is a strenuous task. Even though our country produces almost 1.5 million engineers per year, National Association of Software and Services Companies (NASSCOM) - McKinsey report says that only $25 \%$ of the graduates of the engineering colleges are employable. Also, the above report pointed out that a large number of students end up in Information Technology (IT)/ Information Technology Enabled Services (ITES) related jobs rather than sticking on their core discipline.

The above mentioned scenario resulted in low profile students getting admitted to engineering degree easily than compared to any other arts or science degrees. The teaching process became exacting due to the presence of varied performing level of students like very good, average, below average and very bad in a class. Balancing these students as well as completing the syllabus on time is a challenging task for teachers. Also there are students joining to engineering institutions because of parental compulsions rather than genuine aspiration. Another serious problem in the present time is the addiction of students to electronic gadgets especially to mobile phone, which affected their studies badly.

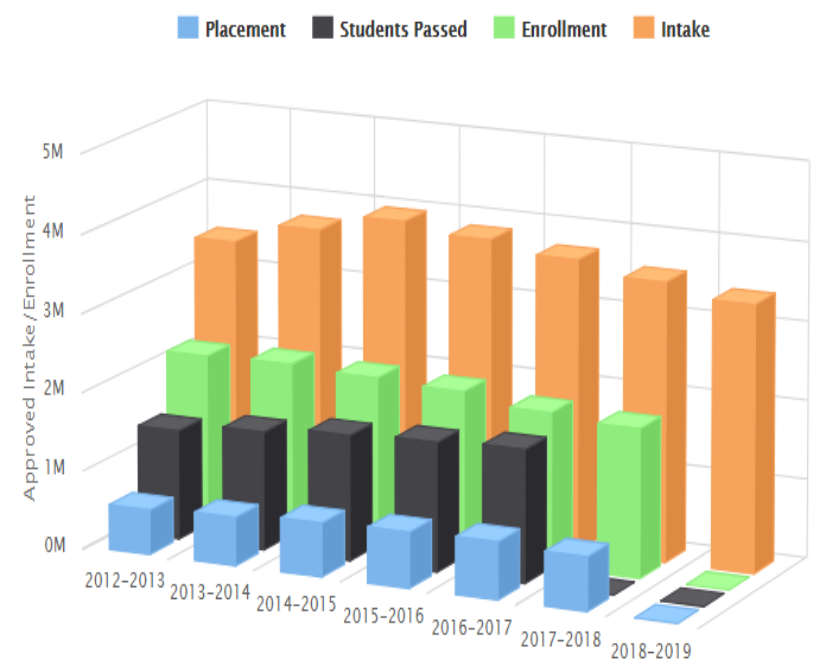

Fig 1: Comparison of Engineering Education in India for past six years (Source: AICTE website) 
Fig 1 showed the variation in the intake number, enrollment quantity, full pass students as well as placement number for the past six years in India. It had seen that the students intake number as well as enrollment increased up to 2014 and thereafter that it declined. But there was a gradual growth in pass percentage and placement rate in the country.

The booming of college in our country happened only at undergraduate level. The number of UG engineering colleges in India is 3400 compared to 570 in China. But students registered for $\mathrm{PhD}$ is only 1000 in India compared to 17,000 in China as per 2010 statistics. This showed that faculty and students of our country are lacking research experience which in turns lowers the position of Indian Universities in the global ranking. Among the789 universities in the country none feature among the first 150 in the world. As per the QS World University ranking 2019 , IIT Bombay occupied the $162^{\text {th }}$ position.

The Engineering education in Kerala also followed similar pattern as that in other states in India. Presently there are 170 Engineering Colleges in Kerala with an intake of 60,884 students. But as per AICTE statistics only 32,114 students were enrolled this year. Around $47 \%$ seats were vacant in the state. According to the data from NTMIS the outturn of graduate engineers reduced from 90\% in 1991 to 55\% in 2008. Fig 2 showed the growth of Engineering Colleges in Kerala.

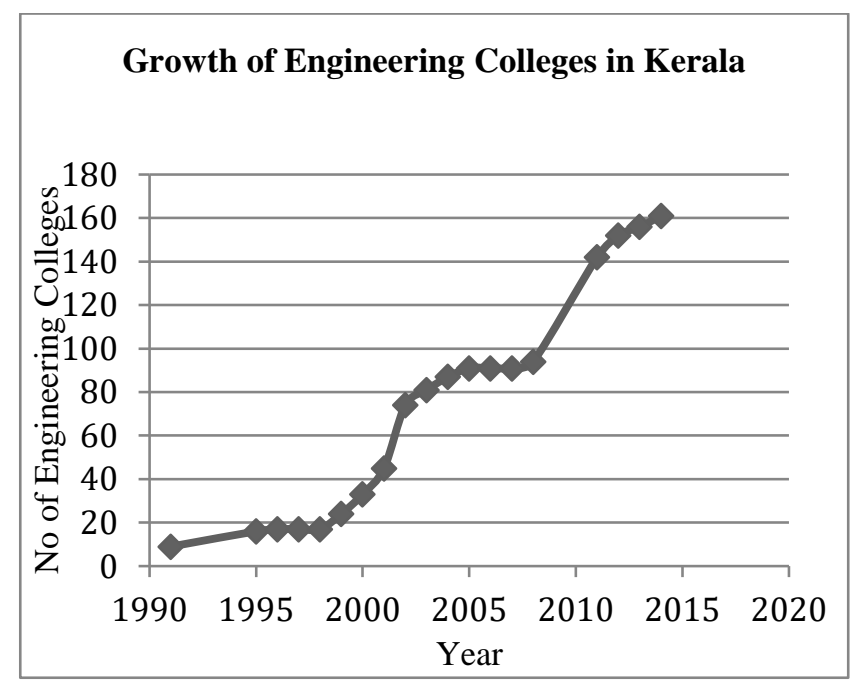

Fig 2: Growth of Engineering colleges in Kerala.

In Fig 3 the variation in the intake number, enrollment quantity, full pass students as well as placement number were shown for the past six years in Kerala. The tendency of the graph matches that with the all India level variation as shown in Fig1.

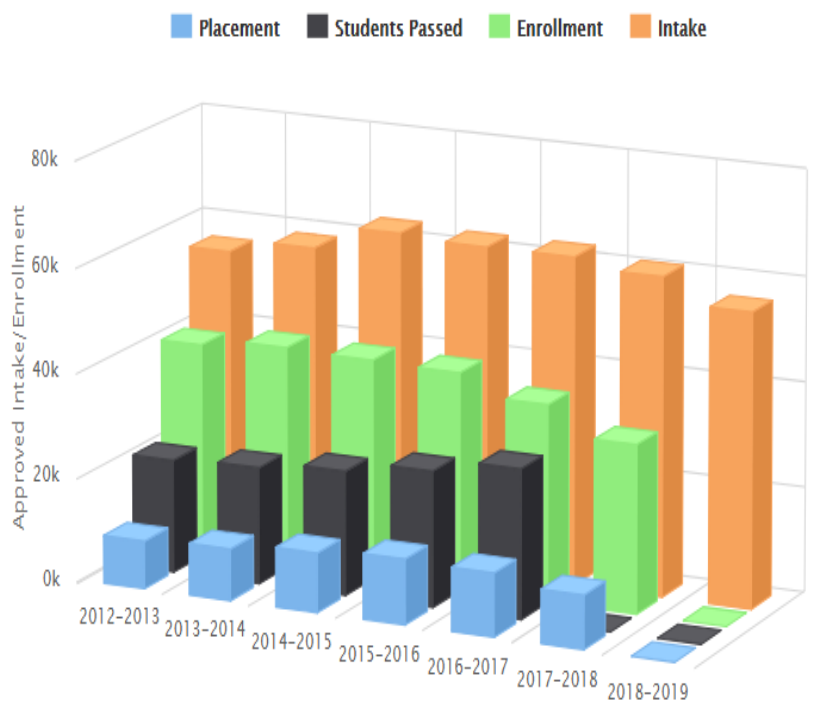

Fig 3: Comparison of Engineering Education in Kerala for past six years (Source: AICTE website)

It is observed that the high court of Kerala constituted an expert committee to carry out surprise inspections in selffinancing institutions to physically verify the availability of qualified faculty and sufficient infrastructure. The committee observed that even though many colleges has sufficient infrastructure, the findings regarding the faculty positions, especially the cadre ratio and pay packages were shocking. Many institutions were running with retired faculty from government colleges occupying higher posts and then with a bunch of fresh engineering graduates. The remuneration for these college teachers in private engineering colleges is far below what the equivalent scales are in the industry. The shortage of motivated and dedicated faculty is a serious problem in Indian Engineering education. Also, the lack of teaching and professional competence of faculty is another factor affecting the Engineering education in our country. Classes are constricted to places for knowledge transfer alone rather than a platform for active learning process.

\section{PROFESSIONAL COMPETENCE}

Competence is a measure of skill that makes a person excellent in the society. Accreditation is a process which measures competence and in which the services and operations of educational institutions or programs are evaluated and verified by an external body to determine whether the applicable and recognized standards are met. ABET and NBA are professional bodies set up to provide guidelines to measure these standards. They come up with 
a set of norms for evaluating a particular program at institution level and at department level. The competence of faculty and students are the major criteria for evaluation. In India only less than $3 \%$ of the engineering colleges got accredited by NBA for different programs and in Kerala about $9 \%$ colleges got accredited by NBA as per 2019 statistics.

\subsection{Evaluation of Faculty Competence.}

Competencies are defined as the personal and professional skill an individual has to possess which makes him superior performers in a society. Teaching learning process becomes successful only if both teacher and student actively involved in the learning process. NBA evaluates the faculty by faculty student's ratio, faculty cadre ratio, qualification of faculty and publications of the faculty. For becoming academically and professionally excellent faculty, he/ she should possess skills in terms of teaching competence, professional competence and communication skills. The parameters influencing faculty competence are excellent teaching skills, technical expertise, critical thinking, scientific and research competence motivation, role model competencies, moral and ethical values, communication competence etc.

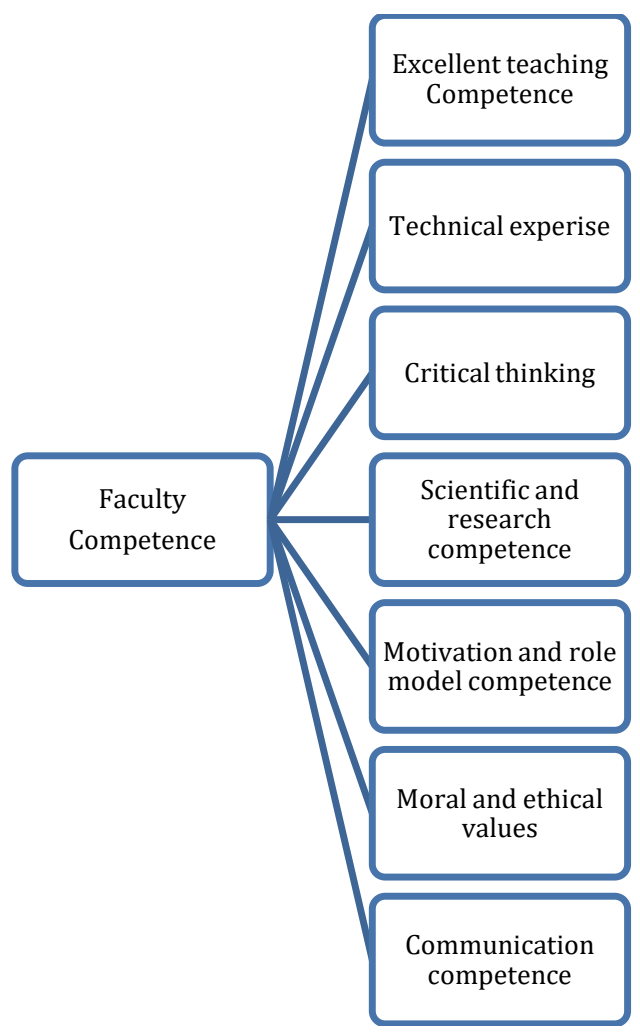

Fig 4 Faculty Competence
Fig 4 showed various parameters of measuring faculty competence that can be evaluated by the following methods;

- Student Ratings

- Peer Ratings

- Self-Evaluation

- Videos Rating

- Student Interviews

- Alumni Ratings

- Employer Ratings

- Administrator Ratings

- Teaching Scholarship

- Teaching Awards

- Learning Outcomes Tests

- Teaching Portfolio

\subsection{Evaluation of Students Competence}

Now the teaching learning process is undergoing revolutionary changes from teacher centric to student centric. As per the NBA guidelines students competence are evaluated based on the parameters like academic performance, success rate, involvement in professional activities and placement and higher studies records as shown below. The academic performance is evaluated from mean of cumulative CGPA average of successful students. Success rate is evaluated based on the mean of success rate for successive three years. Professional activities are evaluated in terms of involvement in professional bodies; publications in technical magazines, entrepreneurship initiatives, awards in inter college events.

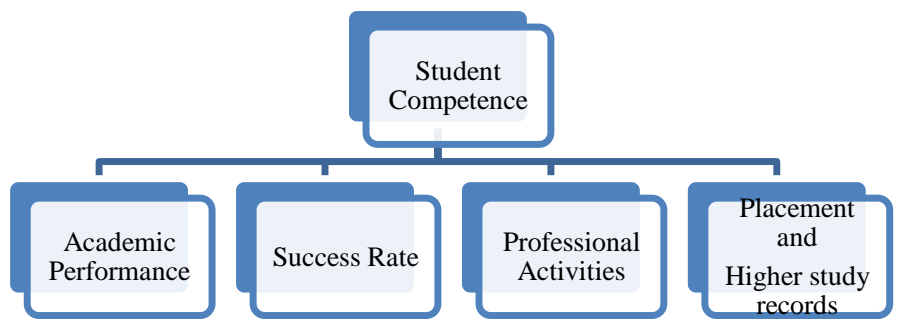

Fig 5. Student Competence

Fig 5 indicates the various parameters of student competence which are measured by attributes for engineering graduates defined by Washington accord as:

- Engineering Knowledge

- Problem Solving

- Design, Development of Solutions

- Investigation

- Modern Tool Usage 
- Engineer and Society

- Environment and Sustainability

- Ethics

- Individual and Team Work

- Communication

- Project Management and Finance

- $\quad$ Life Long Learning

\section{COMPETENCE MEASURING MODEL}

The parameter and attributes for evaluating faculty and students competence were discussed in the previous section. In this section, method for the comparison of each parameter required for assessing competence is described using a multiple criteria decision making tool known as Analytical Hierarchy Process (AHP) developed by Thomas L Saaty (1980) based on mathematics and psychology.

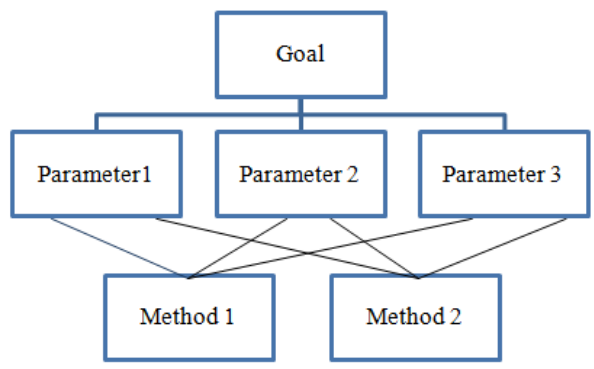

Fig 6. AHP model

In this method first a goal was set as shown in Fig 6. After that a set of evaluation parameters (Level 1) as well as sub criteria (Level 2) were considered, compared and best decision was made among the alternatives. Then AHP generates a weight for each criteria according to decision maker's pair wise comparison. Also depending on the decision makers pair wise comparison a score for each option was put for fixed criteria. Considering these weights and scores a global score and ranking was done in the process. Later consistency of the judgment was checked and synthesized to yield a set of overall priorities for the hierarchy. Then the best parameter was selected based on the highest overall priority value.

In this case the goal was to measure the faculty competence. The parameters (Level 1) were given in Fig 4. The pair wise comparison among those seven parameters was done using Saaty pair wise comparison method as shown in Table 2. It will be a $\mathrm{n} \times \mathrm{n}$ matrix, where $\mathrm{n}$ is the number of parameters. Respondents were told to fill the level of priority in Table 2 based on questionnaire survey for the items given in Table 1. Here the relations among various parameters and different methods for evaluating it discussed in the section 4.2 were established. At this stage the weight calculation, consistency index calculation etc were performed. And based on overall priority value best parameter affecting competence can be chosen.

Table1. Items for questionnaire survey

\begin{tabular}{|c|c|}
\hline Competence & Positive /Negative Indicator of behaviour \\
\hline $\begin{array}{l}\text { Excellent } \\
\text { teaching } \\
\text { competence }\end{array}$ & $\begin{array}{l}\text { - High /Low capacity as an active facilitator } \\
\text { and contributor to the growth of students } \\
\text { - High /Low content and method matching } \\
\text { with the intellectual and absorption } \\
\text { capacity of students. }\end{array}$ \\
\hline $\begin{array}{l}\text { Technical } \\
\text { expertise }\end{array}$ & $\begin{array}{l}\text { - High /Low effort s to up gradation of } \\
\text { knowledge } \\
\text { - High/ Low efforts to combines various } \\
\text { educational methods and elements } \\
\text { - High/ Low able to combine theoretical } \\
\text { knowledge with practical knowledge and } \\
\text { experience }\end{array}$ \\
\hline $\begin{array}{l}\text { Critical } \\
\text { thinking }\end{array}$ & $\begin{array}{l}\text { - High/ Low usage formative and summative } \\
\text { evaluation of knowledge }\end{array}$ \\
\hline $\begin{array}{l}\text { Scientific and } \\
\text { research } \\
\text { competence }\end{array}$ & $\begin{array}{l}\text { - High/ Low teaching and research } \\
\text { capabilities } \\
\text { - Good/Bad in publishing articles at } \\
\text { national as well as international level } \\
\text { - } \begin{array}{l}\text { High/ Low number of honour as an author. } \\
\text { - }\end{array} \text { High/ Low capability to creatively involves } \\
\text { other colleagues and students into scientific } \\
\text { projects and empowers them. }\end{array}$ \\
\hline $\begin{array}{l}\text { Motivation and } \\
\text { role model }\end{array}$ & $\begin{array}{l}\text { - High/ Low personality serves as a positive } \\
\text { role model } \\
\text { - High/ Low capacity to assists students in } \\
\text { developing their personalities. } \\
\text { - High/ Low motivation in his/her action, } \\
\text { every lecture or seminar } \\
\text { - High/ Low ability for self- motivating and } \\
\text { self-keeping ability and the ability to } \\
\text { surmount obstacles }\end{array}$ \\
\hline $\begin{array}{l}\text { Moral and } \\
\text { ethical values }\end{array}$ & $\begin{array}{l}\text { - High/ Low ability of mature, highly } \\
\text { creative, inventive, resourceful and } \\
\text { courageous personality; is always tolerant, } \\
\text { empathic, accommodating and helpful to } \\
\text { others } \\
\text { - High/ Low ability to maintains } \\
\text { objectiveness and impartiality towards any } \\
\text { student. }\end{array}$ \\
\hline $\begin{array}{l}\text { Communication } \\
\text { competence }\end{array}$ & $\begin{array}{l}\text { - High/ Low positive feedback to students } \\
\text { - High/ Low capacity to identify } \\
\text { communication imperfections and prevents } \\
\text { them from occurring. } \\
\text { - High/ Low capacity to communicates } \\
\text { his/her intentions, decisions and matter } \\
\text { taught in a clear, understandable and } \\
\text { inspirational manner.- }\end{array}$ \\
\hline
\end{tabular}

Table 2. Saaty method of pair wise comparison 


\begin{tabular}{|c|c|c|c|c|c|c|c|c|c|c|}
\hline \multirow{2}{*}{ A } & \multicolumn{3}{|c|}{$\begin{array}{c}\text { Strongly } \\
\text { preferred A }\end{array}$} & \multicolumn{4}{c|}{$\begin{array}{c}\text { Strongly } \\
\text { preferred B }\end{array}$} & \multirow{2}{*}{ B } \\
\cline { 2 - 8 } & 9 & 7 & 5 & 3 & 1 & 3 & 5 & 7 & 9 & \\
\hline Parameter & & & & & & & & & & $\begin{array}{c}\text { Parameter } \\
2\end{array}$ \\
1 & & & & & & & & & & $\begin{array}{c}\text { Parameter } \\
3\end{array}$ \\
\hline $\begin{array}{c}\text { Parameter } \\
1\end{array}$ & & & & & & & & & \\
\hline $\begin{array}{c}\text { Parameter } \\
2\end{array}$ & & & & & & & & & $\begin{array}{c}\text { Parameter } \\
3\end{array}$ \\
\hline
\end{tabular}

Students performance were evaluated as per the procedure given in criteria 3 NBA guidelines.

\section{CONCLUSIONS}

In this paper various dimensions of global competence, development of scale for measuring and procedure for validating the scale were described. Also, the present scenario of Indian Engineering education, especially in Kerala was discussed. On one side there was advancement of technology enabling all resources of knowledge available at fingertips and on the other hand the output of education is not reaching the standards. In this paper the factors influencing the competency of faculty and students and a model for evaluating these factors were described.

\section{References}

[1] A. Parkinson, J. Harb, and S. Magleby, "Developing Global Competence in Engineers: What does it mean? What is most important?," Proc. ASEE Annu. Conf. Expo., vol. 023, pp. 113, 2009.

[2] S. S. Klein-gardner and A. Walker, "Defining global competence for engineering students,"ASEE, 2011.

[3] H. K. Ro, L. R. Lattuca, D. Merson, P. "Measuring Engineering Students Contextual Competence," ASEE , 2012.

[4] H. Kyoung Ro, D. Merson, L. R. Lattuca, and P. T. Terenzini, "Validity of the contextual competence scale for engineering students," $J$. Eng. Educ., vol. 104, no. 1, pp. 35-54, 2015.

[5] L. R. Lattuca, D. B. Knight, H. K. Ro, and B. J. Novoselich, "Supporting the Development of Engineers' Interdisciplinary Competence," J. Eng. Educ., vol. 106, no. 1, pp. 71-97, 2017.

[6] J. A. Moreno-Murcia, Y. Silveira Torregrosa, and N. Belando Pedreño, "Questionnaire evaluating teaching competencies in the university environment. Evaluation of teaching competencies in the university," J. New Approaches Educ. Res., vol. 4, no. 1, pp. 54-61,
2015.

[7] J. B. Main and M. L. Sanchez-Pena, "Measuring engineering students' ability to thrive in diverse and global environments," ASEE Annu. Conf. Expo. Conf. Proc., vol. 122nd ASEE, no. 122nd ASEE Annual Conference and Exposition: Making Value for Society, 2015.

[8] M. Waghmare, M. Datar, and R. Hire, "Indian Higher Technical Education Scenario , Issues , Challenges and Achievable Suggestion," Int. Res. J. Adv. Eng. Sci., vol. 2, no. 2, pp. 118-121, 2017.

[9] M. Abdul Rahman and R. Unnikrishnan, "Scope and Challenges of Technical Education," High. Educ. Futur., vol. 2, no. 2, pp. 194-207, 2015.

[10] Reddy, V., "Engineering Education: Challenges, Threats and Opportunities," J.Eng.Educ. Trans., vol. 1707, pp. 165-169, 2015

[11] M.Blaskova, R. Blasko, and A. Kucharcikova, "Competences and Competence Model of University Teachers," Procedia - Soc. Behav. Sci., vol. 159, pp. 457-467, 2015.

[12] H. Brožová, “AHP analysis of teacher's managerial competencies," pp. 67-72, 2011.

[13] T.L. Saaty, The Analytical Hierarchy Process: Planning, Priority Setting, Resource Allocation, New York: McGraw-Hill, 1980.

[14] ABETguidelines https://www.abet.org/ accreditation/ accreditation- criteria.

[15] NBA guidelines www.nbaind.org/

[16] AICTE website: https://www.aicte-india.org/ 
Proceedings 2019 Canadian Engineering Education Association (CEEA-ACEG19) Conference 